Medical Hypotheses 10: 411-424, 1983

\title{
REFINED CARBOHYDRATES - A CAUSE OF SUBOPTIMAL NUTRIENT INTAKE
}

Norman $J$. Temple, Department of Biochemistry, Escuela de Medicina, Box 935, Cayey, Puerto Rico 00634 .

\section{ABSTRACT}

During the refining of carbohydrate foods there is a sharp drop in the concentration of dietary fiber and of various vitamins and minerals. Estimates were made of the effect of refining on the total diet intake of fiber, selenium, folic acid, vitamins $\mathrm{F}$ and $\mathrm{B} 6$, choline, chromium, magnesium, zinc, manganese, copper, sodium and potassium. The health implications of this are discussed and it is concluded that the losses are likely to be detrimental.

\section{INTRODUCTION}

Refined carbohydrates (sugar, white flour, white rice, cornflakes, etc.) are a major component of the Western diet. This has came about almost entirely in the last 100 to 150 years. Furthermore, these food items have became a major source of calories for many Third World peoples who, until quite recently, consumed only a traditional diet.

Cleave (1) and Burkitt and Trowell (2) have argued that refined carbohydrates cause a spectrum of diseases, particularly diabetes (adult onset), obesity, coronary heart disease (CHD) and various diseases of the veins, guns, teeth and colon.

In the production of refined carbohydrates, fractions containing much of the vitamin, mineral and fiber content but little of the carbohydrate are removed (3-5). These are generally fed to livestock or, particularly in the last decade, sold through Health Food shops. Thus refining causes a marked fall in the nutrient: calorie ratio in much of our food.

Man is extremely well adapted to the natural environment (gravity, temperature, sunshine, etc). It follows 
that the diet for which we are most suited is that taken by our hunter-gatherer forebears during human evolutionary development. Its carbohydrate content would obviously be in the unrefined form.

Perhaps the following indicates the extent of our adaptation to available. food. The requirements of various nutrients vary over a range of about ten million from vitamin $\mathrm{BI} 2$ at one extreme to totalprotein at the other. Yet for each most people consume between half and twice the recommended intake. It is reasonable to conclude, therefore, that the optimum intake of vitamins and minerals is that present in a diet rich in unrefined carbohydrates and other natural foods. As Masironi (6) put it, "Over hundreds of thousands of years man became adjusted to the mineral balance of the natural environment..... The natural balance is now perhaps being disrupted by man himself, whose organism has not yet had time to adjust biochemically to these rapid, technologically - induced changes".

\section{LOSS OF NUTRIENTS DURING REFINING}

In order to calculate the impact of carbohydrate refining on nutrient intake a typical Western diet was formulated with sugar and cereals being present entirely in the refined. form. The diet used here is essentially British and is based on The National Food Survey (7). A second diet was derived from this which was as similar as possible except that refined cereals and sugar were replaced with unrefined foods, namely potatoes, apples, bread, unrefined breakfast cereals, peanuts and beans. It is assumed that this would be a typical dietary adaptation if refined carbohydrates were no longer consumed. The data are shown in Table 1.

Due to insufficient information, figures for chromium and selenium are only approximate. Refining causes a loss in the intake of all nutrients under discussion except sodium, the intake of which rises slightly. In some cases the proportion of the ingested nutrient that is absorbed is altered (usually decreased). This needs to be allowed for when assessing the impact of refining.

\section{CORONARY HEART DISEASE}

It is argued elsewhere (18) that the consumption of refined carbohydrates may be the prime cause of CHD. This may be partly explained by a relative deficiency of several of the nutrients discussed here. Since bran and wholewheat bread exert little or no hypocholesterolaemic action (19), evidence has not been included of an anti-atherosclerotic effect of a nutrient if this appears to be secondary to a reduction in the blood cholesterol level. 
Table 1. Nutrient intake in refined and unrefined diets

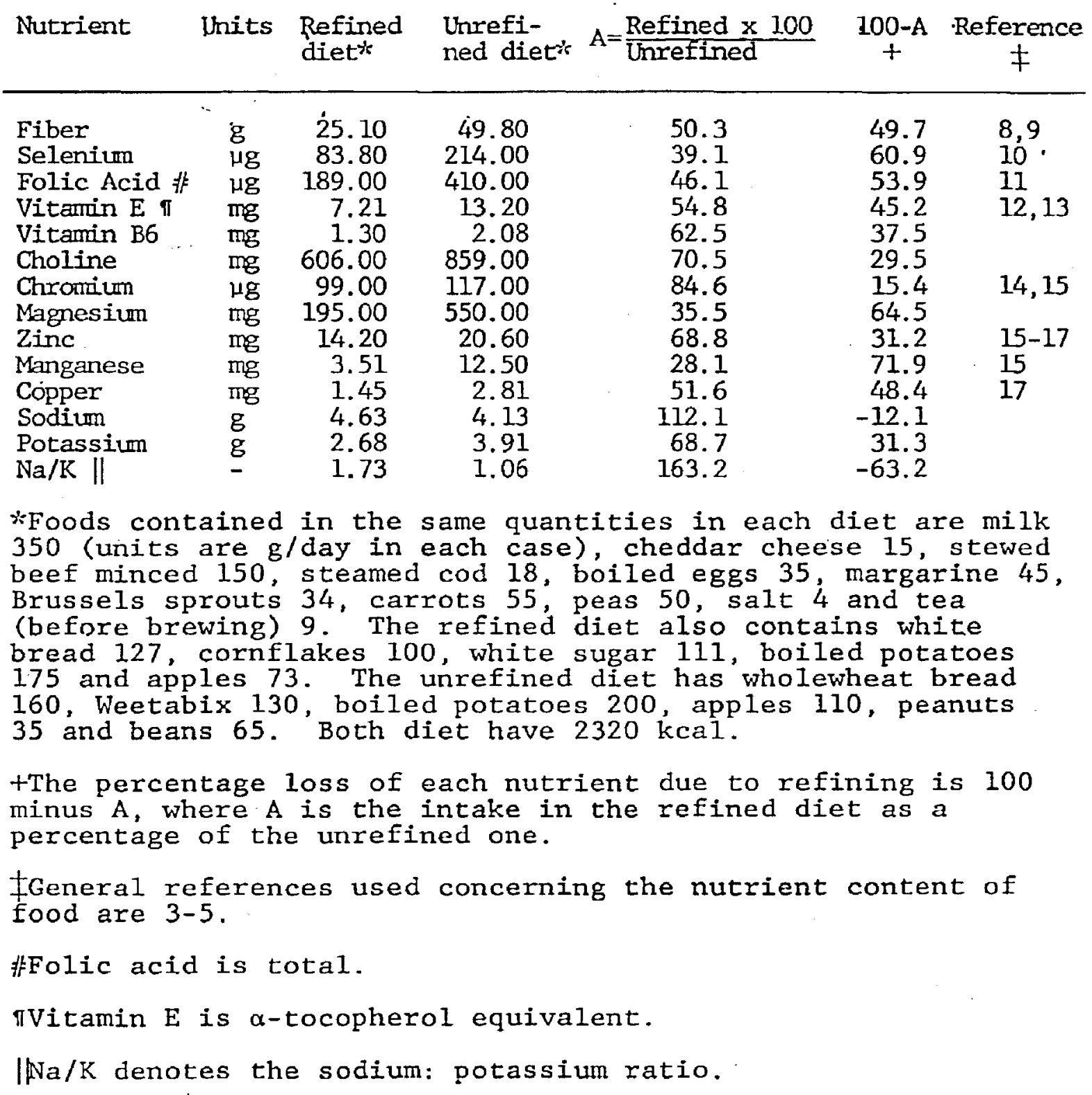

\section{FIBER}

In the diet used here refining has caused a 50 percent loss of dietary fiber (Table 1). It is largely due to the pioneering investigations of Cleave $(1,20)$ that the role of fiber shortage in a variety of disorders became a subject of serious study. Burkitt, Trowell and others (2) further developed Cleave's hypothesis. Cereal fiber much 
increases fecal bulk and consequently shortens the intestinal transit time $(21,22)$. In addition, the softer stool requires much less colonic pressure to expel it (23).

Disorders for which a strong case exists for association them with fiber deficiency are constipation, varicose veins, deep vein thrombosis, hemorrhoids and diverticular disease. Fiber depleted foods facilitate overconsumption of calories and thus partially cause overweight and perhaps adult onset diabetes. The balance of evidence suggests that bowel cancer is caused at least partly by fiber deficiency $(24,25)$ as is pulmonary embolism (23), appendicitis (26) and hiatus hernia.(27). Gallstones may also be included. Wheat fiber reduces the 1ithogenic potential of bile in subjects with gallstones $(28,29)$ or where the bile is supersaturated (30).

\section{SELENIUM}

Refining causes, very approximately, a 39 percent decrease in selenium intake (Table 1). Shamberger and coworkers $(31,32)$ have demonstrated a strong negative correlation between the selenium status of human populations and mortality from coronary and hypertensive heart disease and to a lesser extent cerebrovascular disease. They refer to animal experimentation data in support of these observations.

These findings are paralleled with respect to cancer. For several body sites cancer mortality shows an inverse correlation with selenium status $(33,34)$. Similarly, animal experiments show that the mineral has an impressive anticarcinogenic action $(35-38)$. It also reduces mercury induced mortality in Japanese quail chicks (39-41) and rats (40).

\section{FOLIC ACID}

Refining reduces the intake of folic acid by about 54 percent (Table I). Birth defects are associated with folic acid deficiency (42). Laurence et al. (43) studied women who had previously given birth to a baby with a neural tube defect. A supplement of $4 \mathrm{mg}$ per day given before and during early pregnancy appeared to prevent recurrence.

In a study of elderly patients with folate deficiency and with apparent degeneration of the spinal cord, folate supplementation reversed the neuropathy (44). Folate deficiency also appears. to be associated with mental illness (45).

\section{VITAMIN E}

A 45 percent reduction in vitamin $E$ intake is caused by refining (Table 1 ). Various observations suggest that this 
level of loss may be quite detrimental. The effect of very large (pharmacological) doses will not be considered.

Vitamin E supplementation was observed to increase the proportion of mice surviving to 24 months. This appeared due to protection against a debilitating condition early in life and a reduced incidence of fatal tumors late in life (46).

Dayton et al. (47) treated rats with DMBA (a carcinogenic, polycyclic, aromatic hydrocarbon) and added to their diets coconut oil or safflower seed oil. A vitamin E supplement reduced the incidence of mammary tumors but only in rats fed coconut oil. Possibly the safflower seed oil already had sufficient vitamin $\mathrm{E}$. It is significant that Shamberger et al. (48) observed that vitamin E protects against carcinogen induced chromosome breaks.

Vitamin $E$ has been reported to improve the immune response in mice (49), protect against air pollution (50), liver lipid peroxidation (51) and toxicity from lead (52) and mercury (39).

\section{VITAMIN B6}

A 37 percent $f a 11$ in $B 6$ intake results from the refined diet (Table 1). However, the vitamin is five to ten percent less available from wholewheat bread (53). B6 supplementation has been found to relieve depression in women caused by oral contraception $(54,55)$. It may also protect against tooth decay (56).

\section{CHOLINE}

Refining has caused a 29 percent loss of this nutrient (Table 1). Phosphatidyl choline has been observed to cure experimental atherosclerosis in miniature pigs (57). Brown et al. (58) reported that rabbits with diet-induced atherosclerosis were partly protected by 75 or $500 \mathrm{mg}$ per day choline chloride and to a lesser extent by 10 or $40 \mathrm{mg}$ per day. However, Kritchevsky et al. (59) were unable to confirm this using a diet supplemented with one percent lecithin. There is little evidence for a curative role for lecithin in human CHD (60) though its preventive potential is unexplored.

\section{CHROMIUM}

The loss of chromium due to refining is in the region of 15 percent (Table 1). Chromium is a component of glucose tolerance factor which participates in the hypoglycemic action of insulin (61). Consequently, supplements of the nutrient have been given to persons with diabetes (mainly adult onset). In 40 to 50 percent of cases an improved glucose tolerance has been observed while almost all subjects have shown a normalization (ie reduction) in insulin response (6I). Similar results 
were recently reported in normal subjects $(62,63)$. Indeed, yeast, probably due to its content of chromium, was successfully used to treat diabetes as long ago as 1853 (64).

Chromium deficiency may also be a factor in CHD. It is highly relevant that both an exaggerated insulin response after an oral glucose load and insulin insensitivity are risk factors of CHD $(65-67)$. Studies in the United States have shown a lower aortic chromium level in those who have died of CHD (15) and a lower serum chromium level in those suffering with the disease (68). Similarly, chromium supplementation has reduced experimental atherosclerosis in the rabbit (69).

Lane (70) has reported that persons suffering from myopia tend to have a low hair chromium level.

\section{MAGNESIUM}

Refining causes the loss of 64 percent of magnesium (Table 1). Human studies have assessed the effect on magnesium balance of adding wheat bran or wholewheat bread to the diet. In two such studies most of the extra magnesium was lost in the feces $(71,72)$. However, in a third study there was an appreciable net increase in absorbed magnesium (21). Thus refining causes at least some reduction in absorbed magnesium.

A solid body of evidence associates a magnesium shortfall with CHD (73-77). This is based on epidemiology, clinical studies and animal experimentation. In addition, rat studies suggest that a suboptimal magnesium intake may decrease bone strength (78).

\section{ZINC}

About 31 percent less zinc is consumed as a result of refining (Table 1). However, as zinc absorption is much less efficient from wholewheat bread $(79,80)$ the net amount of zinc absorbed may not be appreciably altered.

\section{MANGANESE AND COPPER}

The losses are 72 percent for manganese and 49 percent for copper (Table 1). As with magnesium and zinc the net loss is almost certainly much more modest.

In the refined diet two thirds of the manganese was derived from tea (the diet is British). Without tea, therefore, the percent loss would have been much greater (though quantitatively the same). 


\section{SODIUM AND POTASSIUM}

Refining raises the sodium intake by 12 percent (due to the cornflakes) while reducing the potassium intake by 31 percent. As a result the diet sodium: potassium ratio rises by 63 percent (Table 1). However, refining appears to increase the proportion of potassium absorbed while having much less effect on sodium $(21,71,81)$. Thus the net increase in the ratio of absorbed sodium: absorbed potassium is of the order of 25 percent.

Much evidence has accrued associating an excess sodium intake with hypertension (82-85). Potassium, on the other hand, tends to counteract the hypertensiogenic effect of sodium (84-87). Refining may therefore be a contributory cause, albeit minor, of hypertension.

\section{CONCLUSIONS}

Nutrition suffers from the legacy of the classic one nutrient-one deficiency disease discoveries. The attitude is still prevalent that unless a clear deficiency disease exists, then an increased consumption of a nutrient is of no possible benefit. This somewhat sterile approach has greatly hindered the concept of sub-clinical deficiency from being accepted. Yet, as demonstrated here, in numerous cases, the likelihood of a particular disease manifesting itself may be appreciably reduced by boosting the intake of a nutrient even when there may be no classical evidence of a deficiency.

In the case of the association between carbohydrate refining and dietary fiber deficiency disease, the evidence is so strong that the hypothesis has gained considerable support fairly quickly. Indeed, for many people, wholewheat bread has became synonymous with fiber. Yet the consequences of refining go far beyond loss of fiber.

With many of the previously discussed nutrient disease associations refining is only a partial cause of sub-clinical deflciency, which is, in turn, only a partial cause of the disease. Nevertheless, many of the diseases discussed here are so widespread and so serious (diabetes, cancer, CHD) that several partial causations add up to a major health problem.

\section{Acknowledgement}

I wish to thank Dr. S.M. El-Khatib for helpful advice.

\section{REFERENCES}

1. Cleave TL. The Saccharine Disease. J Wright, Bristol, 1974. 
2. Burkitt DP, Trowell H, eds. Refined Carbohydrates Foods and Disease: Some Implications of Dietary Fibre. Academic Press, London, 1975.

3. Paul AA, Southgate DAT. McCance \& Widdowson's The Composition of Foods. HMSO, London, 1978.

4. Schroeder HA. Losses of vitamins and trace minerals resulting from processing and preservation of foods. Am J Clin Nutr 24: 562, 1971.

5. Williams RJ. Nutrition Against Dișease. Bantam Books, New York, 1971.

6. Masironi R. Trace Elements in Relation to Cardiovascular Diseases. W.H.O., Geneva, 1974.

7. National Food Survey Committee. Annual Report, Household Food Consumption and Expenditure. HMSO, London, 1981.

8. Southgate, DAT. Dietary fiber: analysis and food sources. Am J Clin Nutr 31: S107, 1978.

9. Southgate DAT, Bailey B, Collinson E, Walker AF. A guide to calculating intakes of dietary fibre. J Human Nutr $30: 303,1976$.

10. Thorn $J$, Robertson $J$, Buss DH, Bunton NG. Trace Nutrients. Selenium in British food. Br J Nutr $\frac{30}{39}$ 391, 1978.

11. Perloff BP, Butrum RR. Folacin in selected foods. J Am Dietet A 70: 161, 1977.

12. Bauernfeind JC. The tocopherol content of food. CRC Crit Rev Food Sci Nutr 8: 377, 1977.

13. McLaughlin PJ, Weihrauch JL. Vitamin E Content of Foods. J Am Dietet A 75: 647, 1979.

14. Schroeder HA, Nason AP, Tipton IH. Chromium deficiency as a factor in atherosclerosis. J Chron Dis 23: 123, 1970.

15. Feldman EB, ed. Nutrition and Cardiovascular Disease. Prentice-Hall, Englewood Cliffs, 1976.

16. Murphy EW, Williams BW, Watt BK. Provisional tables on the zinc content of foods. J Am Dietet A 66: 345, 1975.

17. Freeland-Graves JH, Ebangit ML, Bodzy PW. Zinc and copper content of foods used in vegetarian diets. J Am Dietet A 77: 648, 1980 .

18. Temple NJ. Coronary heart disease - dietary lipids or refined carbohydrates? lled Hypotheses. In press 
19. Truswel1 AS, Kay RM. Bran and blood lipids. Lancet 1: $367,1976$.

20. Cleave TL, Campbell GD. Diabetes, Coronary Thrombosis and the Saccharine Disease. J Wright, Bristol, 1966.

21. Stasse-Wo1thuis $M$, Albers HFF, Van Jeveren JGC, de Jong JW, Hautvast JGAJ, Hermus RJJ, Katan MB, Brydon WG, Eastwood MA. Influence of dietary fiber from vegetables and fruits, bran or citrus pectin on serum lipids, fecal lipids, and colonic function. Am J Clin Nutr 33: i745, 1980 .

22. Cummings JH, Southgate DAT, Branch $W$, Houston $H$, Jenkins DJA, James WPT. Colonic response to dietary fiber from carrot, cabbage, apple, bran and guar gum. Lancet 1: 5, 1978 .

23. Burkitt DP. Varicose veins, deep vein thrombosis, and haemorrhoids: epidemiology and suggested aetiology. Brit Med J 2: 556, 1972.

24. Burkitt DP. Epidemiology of cancer of the colon and rectum. Cancer 28: 3, 1971 .

25. Reddy BS, Cohen LA, McCoy GD, Hill P, Weisburger JH, Wynder EL. Nutrition and its relationship to cancer. Adv Cancer Res 32: 237, 1980.

26. Burkitt DP. The aetiology of appendicitis. Brit J Surg 58: 695, 1971 .

27. Burkitt DP. Hiatus hernia: is it preventable? Am J C1in Nutr 34: 428, 1981.

28. Pomare EW, Heaton KW, Low-Beer TS, Espiner HJ. The effect of wheat bran upon bile salt metabolism and upon the lipid composition of bile in gallstone patients. Am J Surg 21: 521, 1976.

29. McDouga11 RM, Yakymyshyn L, Walker $K$, Thurston OG. Effect of wheat bran on serum lipoproteins and biliary lipids. Can J Surg 21: 433, 1978.

30. McK Watts J, Jablonski P, Toouli J. The effect of added bran to the diet on the saturation of bile in people without gallstones. Am J Surg 135: 321, 1978.

31. Shamberger RJ, Willis CE, McCormack LJ, Selenium and heart disease. III-Blood selenium and heart mortality in 19 states. p59 in Trace Substances in Environmenta1 Health - XIII. (Hemphill DD, ed) University of Missouri, Columbia, 1979. 
32. Shamberger RJ. Selenium in the drinking water and cardiovascular disease. p303 in Drinking Water and Cardiovascular Disease. (Calabrese EJ, Moore GS, Tuthil1 RW, Sieger TL, eds) Pathotox Publishers, Park Forest South, 1980 .

33. Schrauzer GN, White DA, Schneider CJ. Cancer mortality correlation studies, III Statistical associations with dietary selenium intakes. Bioinorg Chem 7: 23, 1977.

34. Shamberger RJ, Tytko SA, Willis CE. Anti-oxidants and cancer.. VI Selenium and age-adjusted human cancer mortality. Arch Environ Health 31: 231, 1976.

35. Schrauzer GN. Trace elements in carcinogenesis. p219 in Advances in Nutritional Research (Draper HH, ed). Plenum, New York, 1979.

36. Jacobs MM. Effects of selenium on chemical carcinogens. Prev Med 9: 362, 1980.

37. Medina D, Shepherd F. Selenium-mediated inhibition of 7,12-dimethylbenz (a) anthracene-induced mouse mammary tumorigenesis. Carcinogenesis 2: 451, 1981.

38. Ip C, Sinha D. Anticarcinogenic effect of selenium in rats treated with dimethylbenz(a)anthracene and fed different levels and types of fat. Carcinogenesis 2: 435,1981 .

39. Stoewsand GS, Bache CA, Lisk DJ. Dietary selenium protection of methylmercury intoxication of Japanese quail. Bul1 Envt Contam Tox 11: 152, 1974.

40. Kling LK, Soares JH. The effect of vitamin E and dietary Iinoelic acid on mercury toxicity. Nutr Rept Int 24: 39,1981 .

41. Ganther HE, Goudie C, Sunde ML, Kopecky MJ, Wagner P, Oh S, Hoekstra WG. Selenium: relation to decreased toxicity of methyl-mercury added to diets containing tuna. Science 175: 1122, 1972.

42. Nelson MM, Forfar Jo. Associations between drugs administered during pregnancy and congenital abnormalities of the fetus. Brit Med J I: 523, 1971.

43. Laurence $\mathrm{KM}$, James $\mathrm{N}$, Miller $\mathrm{MH}$, Tennant $\mathrm{GB}$, Campbel1 H. Double-blind randomised controlled trial of folate treatment before conception to prevent recurrence of neural-tube defects. Brit Med J 282: 1509, 1981.

44. Manzoor M, Runcie J. Folate-responsive neuropathy: report of 10 cases. Brit Med J 1: 1176, 1976. 
45. Carney MWP. Folate-resposive schizophrenia. Lancet 2: 276,1975 .

46. Blackett AD, Hall DA. The effects of vitamin $E$ on mouse fitness and survival. Gerontology 27: 133, 1981.

47. Daytoin $S$, Hashimoto S, Wollman J. Effect of higholeic and high-linoleic safflower oils on mammary tumors induced in rats by 7,12 -dimethylbenz(a) anthracene. J Nutr 107: 1353, 1977.

48. Shamberger RF, Baughman FF, Kalchert SL, Willis CE, Hoffman GC. Carcinogen-induced chromosomal breakage by antioxidants. Proc Nat Acad Sci USA 70: 1461, 1973.

49. Nockels CF. Protective effects of supplemental vitamin E against infection. Fed Proc 38: 2134, 1979.

50. Institute of Food Technologists' Expert Panel on Food Safety and Nutrition. Vitamin E. Nutr Rev 35: 57, 1977.

51. Chen LH. The effect of age and dietary vitamin $E$ on the tissue lipid peroxidation of mice. Nutr Rept Internat 10: 339, 1974.

52. Levander OA, Morris VC, Higgs DJ, Ferretti RJ. . Lead poisoning in vitamin $E$ deficient rats. J Nutr 105: 1481, 1975.

53. Lecklem JE, Miller LT, Perera AD, Peffers DE. Bioavailability of vitamin B-6 from wheat bread in humans. J Nutr 110: 1819, 1980.

54. Adams $P W$, Wynn $R$, Seed $M$, Folkard J. Vitamin B6, depression and oral contraception. Lancet 2: 516, 1974.

55. Adams PW, Wynn R, Rose DP, Seed M, Folkard J, Strong R. Effect of pyridoxine hydrochloride (vitamin B6) upon depression associated with oral contraception. Lancet 1: $897,1973$.

56. Hiliman RW, Cabaud PG, Schenone RA. The effects of pyridoxine supplements on the dental caries experience of pregnant women. Am J CIin Nutr 10: 512, 1962.

57. Samochowiec L, Kadlubowska D, Rozewicka L, Kuzna W, Szyszka K. Investigations in experimental atherosclerosis, part 2. The effect of phosphatidylcholine (EPL) on experimental atherosclerotic changes in miniature pigs. Atherosclerosis 23: 319, 1976.

58. Broun GO, Andrews KR, Corcoran PJV, Van Bruggen J. Lipotropic agents in experimental cholesterol atheros- 
clerosis in rabbits. Geriatrics 4: 178, 1949.

59. Kritchevsky D, Tepper SA, Klerfeld DM, Story JA. Experimental atherosclerosis in rabbits fed cholesterolfree diets : 8. Effects of lecithin. Pharmacol Res Commun 11: 643, 1979 .

60. Hudges RE. Vitamins, lecithin and additives. p201 in Nutrition, Lipids and Coronary Heart Disease. A Global View. (Levy RI, Rifkind BM, Dennis'BH, Ernst N, eds) Raven Press, New York, 1979.

61. Mertz W. Chromium - an overview. $\mathrm{p} 1$ in Chromium in Nutrition and Metabolism. (Shapcott D, Hubert J, eds) Elsevier/North Holland Biomedical Press, Amsterdam, 1979.

62. Riales R, Albrink MJ. Effect of chromium chloride supplementing on glucose tolerance and serum lipids including high-density lipoprotein of adult men. Am J Clin Nutr 34: 2670, 1981.

63. Offenbacher EG, Pi-Sunyer FX. Beneficial effect of chromium-rich yeast on glucose tolerance and blood lipids in elderly subjects. Diabetes 29: 919, 1980.

64. Ro11s R. Brewer's yeast and diabetes. Brit Med J $1: 905,1977$.

65. Pyorala K. Relationship of glucose tolerance and plasma insulin to the incidence of coronary heart disease: results from two population studies in Finland. Diabetes Care 2: 131, 1979.

66. Welborn TA, Wearne $\mathrm{K}$. Coronary heart disease incidence and cardiovascular mortality in Busselton with reference to glucose and insulin concentrations. Diabetes Care 2: 154,1979 .

67. Ducimetiere P, Eschwege L, Papoz JL, Claude RJR, Rosselin G. Relationship of plasma insulin levels to the incidence of myocardial infarction and coronary heart disease mortality in a middle-aged population. Diabetologia 19: 205, 1980.

68. Newman HAI, Leighton RF, Lanese RR, Freedland NA. Serum chromium and angiographically determined coronary artery disease. Clin Chem 24: 541, 1978.

69. Abraham AS, Sonnenblick M, Eini M, Shemesh O, Batt AP. The effect of chromium on established atherosclerotic plaques in rabbits. Am J Clin Nutr. 33: 2294, 1980.

70. Lane BC. Calcium, chromium, protein, sugar and accom- 
modation in myopia. Doc Ophthal Proc Series 28: 141, 1981 .

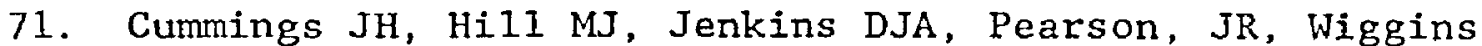
HS. Changes in fecal composition and colonic function due to cereal fiber. Am J Clin Nutr 29: 1468, 1976.

72. Walker ARP, Fox FW, Irving JT. Studies in human mineral metabolism. I The effect of bread rich in phytate phosphorus on the metabolism of certain mineral salts with special reference to calcium. Biochem J 42: 452, 1948.

73. Seeling MS, Heggtveit HA. Magnesium interrelationships in ischaemic heart disease: a review. Am $J$ Clin Nutr $27: 59,1974$.

74. Elwood PC, Beasley WH. Myocardial magnesium and ischaemic heart disease. Artery 9: 200, 1981 .

75. Chipperfield B, Chipperfield JR. Magnesium and the heart. Am Heart J 93: 679, 1977.

76. Karppanen H. Epidemiological studies on the relationship between magnesium intake and cardiovascular diseases. Artery 9: 190, 1981.

77. Davis WH, Ziady $F$. The effect of oral magnesium chloride therapy on the QTc and QUc intervals of the electrocardiogram. S Afr Med J 53: 591, 1978.

78. Heroux O, Peter D, Tanner A. Effect of chronic suboptimal intake on magnesium and calcium content of bone and on bone strength of the rat. Can J Physiol Pharmacol 53: 304, 1975 .

79. Sandstrom B, Arvidsson B, Cederblad A, Bjorn-Rasmussen E. Zinc absorption from composite mea1s. I The significance of wheat extraction rate, zinc, calcium and protein content in meals based on bread. Am J Clin Nutr 33: 739, 1980 .

80. Reinhold JG, Foradji B, Abadi P, Ismail-Beigi F. Decreased absorption of calcium, magnesium, zinc and phosphorus by humans due to increased fiber and phosphorus consumption as wheat bread. J Nutr 106: 493, 1976.

81. Eastwood MA, Mitche11 WD. The effect of bran on the excretion of faecal cations. Proc Nutr Soc 35: 78A, 1976.

82. Trowell H. Hypertension, obesity, diabetes mellitus and coronary heart disease. p3 in Western Diseases: Their Emergency and Prevention. (Trowell HC, Burkitt DP, eds) Edward Arnold, London, 1981. 
83. Tobian L. The relationship of salt to hypertension. Am J CIin Nutr 32: 2739, 1979.

84. Meneely GR, Battarbee HD. High sodium-low potassium evironment and hypertension. Am J Cardiol 38: 768, 1976.

85. Heyden $S$, Hames CG. Dietary effects on blood pressure. Nutr Metab 24 (Supp1t 1): 50, 1980.

86. Parfrey PS, Condon K, Wright P, Vandenburg MJ, Holly JMP, Goodwin FJ, Evans SJW, Ledingham JM. Blood pressure and hormonal changes following alteration in dietary sodium and potassium in young men with and without a familial predisposition to hypertension. Lancet 1: 113, 1981.

87. Parfrey PS, Vandenburg MJ, Wright P, Holly JMP, Goodwin FJ, Evans SJW, Ledingham JM. Blood pressure and hormonal changes following alteration in dietary sodium and potassium in mild hypertension. Lancet 1: 59, 1981. 